\section{EAST AFRICAN AGRICULTURAL AND FISHERIES RESEARCH COUNCIL \\ REPORT FOR 1956}

$\mathrm{T}$ $\mathrm{HE}$ annual report of the East African Agricultural and Fisheries Research Council* for the year ended June 30, 1956, comprises a general review and the separate reports of the Organizations for Agricultural and Forestry Research, for Veterinary Research, for Fishery Research, for Marine Fisheries Research, and for Trypønosomiasis Research, each of which includes a list of staff and of papers published during the period. A Trypanosomiasis Research Co-ordinating Committee was established during the year and it is believed that co-ordination is now adequate. Generally, the East African Agriculture and Forestry Research Organization gives preference to problems of immediate importance to more than one territory, which require several years research, and to problems requiring both a central research team or co-ordinating research officer and territorial field officers. Forestry nursery work has been very successful in developing improved methods of managing tree seedlings. Experimental work on the conservation of water by fallows at Kangwa has been completed and the first stage of the work on assessing the fertilizer needs of a soil is nearing completion; an investigation is to be undertaken of factors which influence the rate of oxidation of organic matter in tropical soils. A revised edition of the Soil Map of East Africa is in preparation and work continued on the genetical analysis of the resistance of maize to American rust disease. The survey of insects attack. ing East African forest trees has been largely concerned with wood-boring species, while studies of the digestibility of protein in fodders have shown that within narrow limits there is a unique relation between the crude protein content of a feed and its apparent digestibility and that this relation is the same for all ruminants.

Substantial progress was made in the establishment of the East African Veterinary Research Organization and production of caprinized and leprinized rinderpest vaccines was not seriously interrupted. A satisfactory technique for producing high-quality pleuropneumonia antigen was devised using a new tryptose broth medium and a modified Lister separator for concentrating the organisms.

The annual report of the East African Marine Fisheries Research Organization for 1955-56 reviews briefly the work of the previous four years. A pre. liminary report on the distribution in place and time of the pelagie fishes will be published shortly, but this study still requires a long series of patient observations and its scope is being extended.

The East African Trypanosomiasis Research Organization was almost at full strength for the first time in 1956. It can now be affirmed that $G$. morsitans and $G$. swynnertoni normally find most feeds from wart-hog, seldom, if ever, from zebra and hartebeest, and very rarely from impala; but given the opportunity $G$. morsitans takes the greater part of its feeds from hippopotamus. In general, research on the trypanosome in East Africa is far behind that on the tsetse fly, and a chief problem is the extremely com-

- East Africa High Commission. Annual Report of the East African Agricultural and Fisheries Research Council, 1955-1956. Pp. ii +56. (Nairobi : Government Printer, 1957.) Sh. 3. plex problem of the 'trypanosome challenge'. At the Central Trypanosomiasis Research Laboratory the whole life-cycle of trypanosomes, particularly those of the polymorphic group, is under investigation, but three of the larger projects are epidemiological investigations. The pilot schemes for tsetse reclamation are being wound up and the Organization will no longer include that field among its activities.

The annual report of the East African Fisheries Research Organization* for the year ended June 30, 1956, includes a list of publications by its staff and by visiting scientists and a paper on "The Efficient Utilization of the Fisheries of Lake Victoria", setting forth the views of the Organization on retention of the existing restrictions on fishing. Appendixes include papers on the distribution of sulphur in the muds, water and vegetation of Lake Victoria and its fixation in the bottom deposits; observations on seasonal and diurnal changes of stratification in Lake Victoria; the planktonic Crustacea of Lake Victoria; effects of D.D.T. on the feeding habits of insectivorous fishes in the Victoria Nile ; ring formation in the scales of Tilapia esculenta; and a preliminary note on investigations being undertaken on the physiology of reproduction in fishes. Studies on the water of Lake Victoria were severely handicapped by the absence of a hydrologist, but work on the food and feeding habits of piscivorous and insectivorous fishes in Lake Victoria is near completion. An investigation was started on the growth-rate and general ecology of young Clarias messambicus in the first two years of life, and research on the taxonomy and ecology of the seventy Haplochromis species in Lake Victoria is virtually complete.

East Africa High Commission. East African Fisheries Research East African Fisheries Research Organization, 1956.)

\section{TECHNICAL COLLEGE LIBRARIES}

TNDER the title "Standards for Library Service in Colleges of Technology", a Committee of the Sub-Section for Colleges of 'T'echnology and Further Education, University and Research Section of the Library Association, under the chairmanship of L. L. Ardern, has compiled a useful report* containing basic recommendations for libraries in colleges of advanced technology, regional technical colleges and those area technical colleges which have advanced full-time or sandwich courses. The report sets out to give broad guiding principles based on the experience of its members, and the minimum standards set forth should not only be of assistance to local education authorities, principals and others, including librarians engaged in the provision of libraries, but should also indicate how much remains to be done before technical college libraries can assume the regional functions that have lately been suggested for them.

The principal recommendations comprise appointment of a suitably experienced chartered librarian, with the status recommended by the Library Association Council, before the library is planned, and sufficient full-time staff to ensure that the library can

* Standards for Library Service in Colleges of Technology : a Report compiled by a Committee of the Sub-Section for Colleges of Technology and Further Education, University and Research Section, College of Technology, 1957.) $3 s, 6 d$. 